\title{
PENGEMBANGAN AGRIBISNIS SAYURAN DAN BUAH- BUAHAN DI DAERAH AGROWISATA GUMANTAR, KABUPATEN LOMBOK UTARA
}

\author{
Taslim Sjah*), Wuryantoro, Sri Supartiningsih, Sri Maryati \\ Program Studi Agribisnis Universitas Mataram \\ Jalan Majaphit Nomor 62 Mataram 83125 \\ *)alamat korespondensi: taslim.sjah@unram.ac.id
}

\begin{abstract}
ABSTRAK
Kabupaten Lombok Utara (KLU) sedang giat melakukan pembangunan di segala bidang, termasuk bidang ekonomi, antara lain dengan pengembangan agrowisata pada lokasi-lokasi yang potensial, seperti di Desa Gumantar, Kecamatan Kayangan. Pengembangan agrowisata ini salah satunya adalah dengan pengembangan sayuran dan buah-buahan. Untuk memperoleh manfaat maksimum dari produksi maka usaha tanaman dilakukan dengan pendekatan agribisnis, memadukan kegiatan dari hulu hingga hilir, dari pra produksi hingga ke konsumen. Wilayah yang ditetapkan sebagai lokasi kegiatan pengabdian kepada masyarakat adalah Desa Gumantar Kecamatan Kayangan Kabupaten Lombok Utara. Tujuan kegiatan ini secara umum adalah untuk meningkatkan pendapatan pelaku usaha dalam wilayah agrowisata tersebut. Tahapan kegiatan untuk mencapai tujuan umum tersebut dilakukan melalui tujuan-tujuan khusus untuk meningkatan kemampuan teknis dan manajemen dalam bisnis terkait. Cakupan materi dirancang untuk mencapai efisiensi dan efektivitas operasi, dari dua sisi kegiatan bisnis yaitu peningkatan penerimaan dan pengurangan biaya operasi bisnis. Penyampaian materi kegiatan pengabdian kepada masyarakat dilakukan dengan metode ceramah dan diskusi. Evaluasi terhadap kegiatan menunjukkan hasil positif berupa peningkatan pengetahuan dan motivasi usaha karena adanya potensi peningkatan keuntungan yang diperoleh dengan penerapan pengetahuan yang telah diberikan. Oleh karena itu kegiatan semacam ini perlu dilakukan lagi di lokasi-lokasi baru maupun pada bidangbidang bisnis baru.
\end{abstract}

Kata Kunci: Agribisnis, Agrowisata, Buah-buahan, Sayuran, Kabupaten Lombok Utara 


\section{PENDAHULUAN}

Indonesia terus melakukan pembangunan pertanian dengan tujuan awal meningkatkan produksi pertanian dan berujung pada peningkatan pendapatan pelakunya, yang pada jangka panjang diharapkan mampu meningkatkan kondisi perekonomian Indonesia secara umum. Berbagai upaya dilakukan untuk membangun pertanian, antara lain saat ini dilakukan dengan pendekatan agrowisata dan agribisnis.

Pendekatan agrowisata memadukan pertanian dengan wisata dengan memanfaatkan keindahan alam pertanian (Walker, 2009; Wikipedia, 2016) termasuk sayuran dan buah-buahan, ditambah dengan manfaat ekonomi yang mungkin diperoleh. Pendekatan agribisnis selanjutnya menekankan pada keterpaduan antar sub sistem dalam sistem agribisnis, dimulai dengan sub sistem input, dilanjutkan dengan sub sistem usahatani, pengolahan hasil (agroindustri), pemasaran produk, dan jasa penunjang untuk sistem agribisnis (AHRDB, 2001; Cramer, Jensen, \& Southgate, 1997; McGregor, 1997; Soekartawi, 1991).

Pengembangan agrowisata di Desa Gumantar, Kecamatan Kayangan, Kabupaten Lombok Utara pada tahun 2018 mencapai tahun ketiga. Masyarakat di lokasi tersebut telah mengembangkan beberapa tanaman yang bernilai keindahan dan bernilai ekonomi tinggi seperti sayuran dan buah-buahan. Agar tanaman-tanaman yang diusahakan dapat memberikan manfaat atau dampak positif yang lebih besar lagi dari yang telah diperoleh saat ini maka kegiatan perlu dilakukan dengan pendekatan agribisnis. Dengan pendekatan ini maka semua kegiatan perlu dilakukan secara efisien dan efektif sejak dari sub sistem pertama (sub sistem input), berlanjut ke sub sistem usahatani, sub sistem pengolahan hasil (agroindustri), sub sistem pemasaran, dan akhirnya pada sub sistem penunjang. Pelaku agrowisata perlu menggunakan pendekatan agribisnis ini, yang pada prinsipnya adalah melakukan efisiensi pemanfatan sumberdaya yang ada dan melakukan peningkatan efektivitas kegiatan dalam memanfaatkan sumberdaya tersebut.

Oleh karena itu maka pelaku usaha agrowisata di lokasi tersebut perlu memahami atau lebih tepatnya memiliki pengetahuan dan keterampilan tentang pengembangan agribisnis tanaman sayuran dan buah-buahan yang telah mereka usahakan. Situasi yang dipantau dalam dua tahun kegiatan yang berjalan, menunjukkan bahwa petani pelaku usahatani dalam 
wilayah pengembangan agrowisata tersebut telah memiliki pengetahuan dan keterampilan khususnya dalam kegiatan usahatani. Namun, pengetahuan dan keterampilan dalam sub-sub sistem agribisnis selain sub sistem usahatani masih dinilai kurang dan karenanya memerlukan peningkatan. Itulah alasan utama dilakukan kegiatan pengabdian ini, yaitu melakukan transfer ilmu pengetahuan tentang pengembangan kegiatan pertanian dengan menggunakan pendekatan agribisnis. Tulisan ini mendeskripsikan apa yang telah dilakukan beserta dampak kegiatan pengabdian yang telah dilakukan.

\section{METODE KEGIATAN}

Mitra kegiatan ini adalah masyarakat desa (Desa Gumantar, Kecamatan Kayangan, Kabupaten Lombok Utara). Kelompok masyarakat yang menjadi target kegiatan adalah petani beserta keluarganya (istri) di kawasan pengembangan agrowisata Desa Gumantar. Permasalahan mitra terkait dengan pengembangan agrowisata yang baru berjalan ini adalah sebagai berikut:

1. Kelemahan dalam pemilihan atau penentuan jenis tanaman (sayuran dan buah-buahan) yang diusahakan atau diintroduksikan ke lokasi baru tersebut
2. Kelemahan penentuan jadwal produksi bagi tanaman yang diusahakan, agar memperoleh keuntungan dari pergerakan harga produksi.

3. Kelemahan penguasaan teknologi produksi untuk tanaman yang baru diusahakan.

4. Kelemahan dalam pengetahuan dan teknologi panen, pasca panen, dan pengolahan hasil sayuran dan buah-buahan yang diusahakan.

5. Pemasaran produk masih dilakukan secara apa adanya, dan umumnya mengandalkan pembeli luar yang datang kepada produk atau mereka, sehingga pemasaran hampir sama saja dengan penjualan produk. Oleh karena itu, pemasaran merupakan hal penting untuk ditangani agar kegunaan produk meningkatkan dalam bentuk, waktu, tempat, dan kepemilikan.

6. Kemampuan pelaku usaha dinilai terbatas, misalnya dalam menentukan harga, ukuran produk, kemasan, dan karenanya dinilai penting untuk ditingkatkan agar pengusaha (masyarakat) tersebut dapat bersaing.

Untuk mengatasi permasalahan-permasalahan mitra yang telah disebutkan diatas maka perlu dilakukan intervensi. Intervensi yang perlu dilakukan 
diharapkan mampu meningkatkan kondisi berbagai aspek agribisnis sayuran dan buah-buahan yang perlu diusahakan sejak dari hulu hingga hilirnya. Merujuk kepada masalah mitra yang telah dipaparkan diatas maka intenvensi yang dilakukan adalah dalam hal-hal terkait seperti pemilihan jenis usaha (tanaman) (Sjah, Rosmilawati, \& Zainuri, 2012); manajemen produksi (Ahyari, 1996; Beierlein, Schneeberger, \& Osburn, 1986; Downey \& Erickson, 1987); pengetahuan dan teknologi budidaya (Badan Litbang Pertanian RI, 2017); pengetahuan dan teknologi panen, pasca panen, dan pengolahan hasil (Zainuri, Handayani, Werdiningsih, \& Widyasari, 2017); pemasaran produk (Kotler, 1997; Swastha \& Irawan, 2005); dan manajemen usaha (Covello \& Hazelgren, 2004; Sjah et al., 2012; Tohir, 2017).

Dengan berbagai upaya dan intervensi tersebut maka diharapkan masalah mitra dapat diatasi sehingga kondisi secara keseluruhan menjadi lebih baik di masa datang, yaitu terjadi peningkatan dalam ekonomi, keterampilan (skills), pengetahuan, dan komunikasi bisnis.

$$
\text { Kegiatan pengabdian ini }
$$

dilakukan di Desa Gumantar Kecamatan Kayangan Kabupaten Lombok Utara. Pada desa ini telah dilakukan pengembangan agrowisata melalui pengembangan sayuran dan buah-buahan yang menarik dan bernilai ekonomi tinggi. Sasaran dari kegiatan pengabdian ini adalah petani dan anggota keluarganya di kawasan pengembnagan tersebut. Petani dan anggota keluarga petani diharapkan dapat melakukan usahatani sayuran dan buah-buahan secara terpadu dalam pendekatan sistem agribisnis, dan dilakukan secara efisien dan efektif, sehingga dapat memberikan kontribusi pada peningkatan pendapatan rumah tangga petani.

Tahapan

kegiatan pengabdian pada masyarakat yang dilakukan adalah berikut:

1. Tahap persiapan: Survei pendahuluan untuk mengidentifikasi persoalan yang terkait dengan pelaksanaan sistem dan manjemen agribisnis sayuran dan buah-buahan di lokasi pengabdian.

2. Tahap pelaksanaan kegiatan: Kegiatan yang dilakukan adalah penyuluhan, praktek/demontrasi dan pembinaan langsung oleh tim pelaksana kegiatan. .

3. Tahap evaluasi: dilakukan sebagai peningkatan kualitas kegiatan pengabdian selanjutnya.

Peserta pelatihan merupakan para petani pria (bapak tani) dan wanita (ibu tani). Kelompok wanita menerima materi penyuluhan di 
baah pohon, sedangkan kelompok pria menerima penyuluhan di berugak. Jumlah peserta dibatasi hingga 20 orang saja untuk mendapatkan efektivitas kegiatan. Ukuran kelas ini sesuai dengan banyak teori efektivitas pengajaran yang dikemukakan dalam proses belajar mengajar. Dalam praktiknya, tim penyuluh memperkirakan bahwa peserta penyuluhan dapat mendengarkan materi yang disampaikan, sehingga diharapkan timbul pemahaman terhadap informasi yang disampaikan. Penyuluhan dilakukan secara lisan tanpa alat bantu berenergi listrik, seperti LCD atau komputer.

Metode yang digunakan dalam pelatihan ini adalah metode ceramah dan diskusi. Ceramah disertai dengan peragaan untuk memfasilitasi pemahaman peserta penyuluhan. Pertanyaan diajukan oleh para peserta dan tim penyuluh menjawab pertanyaan secara bergiliran sesuai dengan keahlian atau materi yang disampaikan.

HASIL DAN PEMBAHASAN

\section{Realisasi kegiatan}

Kegiatan ini dilaksanakan untuk mencapai tujuan yang telah disebutkan pada bagian tujuan kegiatan ini. Materi yang diberikan untuk penambahan pengetahuan dan/atau keterampilan adalah sesuai dengan tujuan yang telah ditetapkan, dengan rincian materi kegiatan terdapat pada lampiran laporan ini.

Kegiatan dilaksanakan di Dusun Amor-amor, Desa Gumantar, Kecamatan Kayangan, Kabupaten Lombok Utara. Kegiatan dilakukan di bawah pohon dan di berugak yang ada di lokasi dekat usahatani kelompok masyarakat Dusun Amoramor, Desa Gumantar. Peserta pelatihan terdiri atas bapak-bapak tani dan ibu-ibu tani, dan mereka dibagi menjadi 2 kelompok, yaitu kelompok bapak tani dan kelompok ibu tani. Kegiatan ini dilakukan secara bersamaan dengan kegiatan penyuluhan oleh kelompok lain. Kelompok ibu tani menerima penyuluhan di bawah pohon, sedangkan kelompok bapak tani menerima penyuluhan di berugak. Beberapa photo kegiatan disampaikan pada gambar berikut ini. 


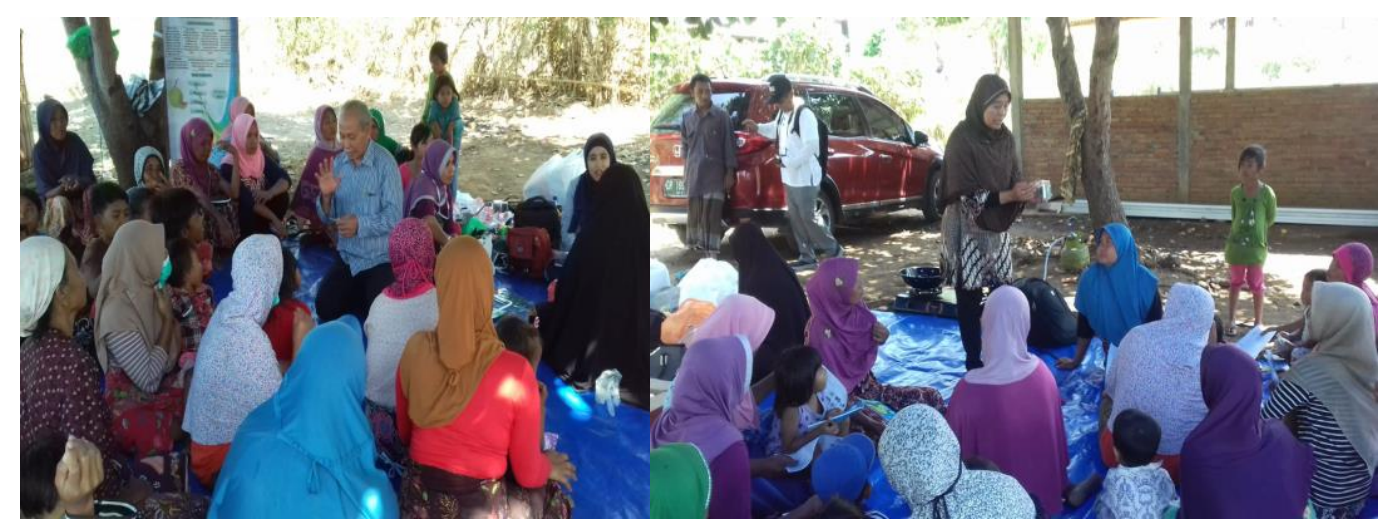

Gambar 1. Kegiatan penyuluhan sebagai bagian dari pengabdian kepada masyarakat

Materi penyuluhan adalah seperti telah dirincikan pada bagian pelaksanaan kegiatan, yaitu meliputi: Pemilihan jenis tanaman; Manajemen produksi; Pengetahuan dan teknologi budidaya; Pengetahuan dan teknologi panen, pasca panen, dan pengolahan hasil; Pemasaran produk; Manajemen usaha; dan lain-lain yang terkait. Materi penyuluhan disampaikan secara bergiliran antar kelompok bapak dan ibu tani dan juga antar pelaksana penyuluhan (pemateri), sehingga kedua kelompok memperoleh semua materi yang disuluhkan.

\section{Evaluasi kegiatan}

Kegiatan telah dilaksanakan sesuai dengan rencana, termasuk tentang materi, waktu, dan hasil yang diharapkan. Dengan kata lain, pelaksanaan kegiatan ini dinilai efektif. Efektivitas hasil diperkuat dengan komunikasi yang baik, interaktif, dan berkelanjutan selama pelatihan dan setelah selesainya kegiatan penyuluhan ini. Peserta pelatihan menanyakan banyak hal kepada narasumber dan mereka antusias. Tim penyuluh juga sangat bersimpati terhadap kesulitan yang sedang dialami oleh peserta penyuluhan, yang sebagina masih merasakan kesedihan dan shock karena kejadian gempa yang berulang-ulng di lokasi tersebut dan dengan skala gempa yang relatif besar dan telah berdampak merusak bangunan, bahkan lahan. Beberapa peserta menyatakan bahwa mereka akan memanfaatkan materi pelatihan untuk dipraktikkan. Peserta juga berhasrat untuk mendapatkan pelatihan tambahan dan bimbingan lanjutan dalam beberapa aspek, antara lain aspek kehidupan tanaman dan bisnisnya, agar manfaat kegiatan dapat dirasakan. Dengan gurau mereka menyampaikan keinginan untuk dikunjungi kembali di waktuwaktu mendatang. 


\section{Faktor pendukung dan penghambat}

Ada cukup banyak faktor yang mendukung pelaksanaan kegiatan penyuluhan ini dan pelaksanaan hasil-hasilnya. Termasuk sebagai faktor pendukung ini adalah antusiasme dan kesadaran peserta untuk meningkatkan kondisi perekonomian mereka, terutama karena terdampak negatif dari gempa yang terjadi. Faktor ini menggerakkan mereka (petani dan keluarga) untuk mengikuti kegiatan penyuluhan dan kemudian mengaplikasikan dengan kaidah (agri) bisnis.

Selain itu, masyarakat desa setempat merupakan masyarakat yang suka bekerjasama untuk kepentingan bersama (bergotong royong merupakan tradisi yang rajin dipraktikan). Kondisi ini merupakan modal untuk maju bersama dalam suatu bisnis, termasuk agribisnis yang bisa dikelola secara kelompok, ataupun secara individual.

Sebaliknya ada juga faktor penghambat seperti jarak lokasi yang cukup jauh sehingga agak menyulitkan untuk bisa sering-sering bertemu dengan anggota kelompok masyarakat lainnya. Demikian juga dengan jauhnya desa ini dengan pusat-pusat ekonomi sehingga untuk pemasaran produk akan memerlukan transportasi yang jauh dan biaya yang relatif tinggi. Di atas semua hambatan yang telah disebutkan juga ada kondisi yang belum tenang dan belum nyaman dalam kehidupan mereka Oleh karena itu, faktorfaktor yang menghambat ini perlu dipikirkan pemecahannya, antara lain dengan membangun atau memperbaiki kondisi jalan dan perumahan penduduk. Banyak pihak perlu bekerjasama untuk mengatasi masalah ini.

\section{KESIMPULAN DAN SARAN}

\section{Kesimpulan}

Evaluasi terhadap kegiatan menunjukkan hasil positif berupa peningkatan pengetahuan dan semangat berusaha karena adanya potensi peningkatan keuntungan yang diperoleh dengan penerapan pengetahuan yang telah diberikan. Oleh karena itu kegiatan semacam ini perlu dilakukan lagi di lokasi-lokasi baru maupun pada bidang-bidang kegiatan (bisnis) baru. Kegiatan penyuluhan seperti ini perlu dilakukan karena dibutuhkan oleh masyarakat setempat dan potensi sumberdaya alam dan sumberdaya manusia untuk melakukan kegiatan tersebut cukup besar.

\section{Saran}

Hasil positif dan efektif dari kegiatan yang telah dilaksanakan mengarahkan kepada saran bahwa kegiatan semacam ini perlu diperbanyak di lokasi desa setempat, atau ke lokasi-lokasi baru sesuai 
dengan potensi wilayah yang bersangkutan, dan juga pada bisnisbisnis (kegiatan-kegiatan) baru.

\section{UCAPAN TERIMA KASIH}

Terima kasih yang sebesarbesarnya disampaikan Universitas Mataram yang telah mendanai kegiatan pengabdian kepada masyarakat ini. Juga, disampaikan terima kasih kepada pihak-pihka lain yang telah memberikan bantuan fisik dan moral untuk kelancaran kegiatan ini, khususnya para narasumber kegiatan dan peserta kegiatan pengabdian ini.

\section{DAFTAR PUSTAKA}

AHRDB. 2001. Model agribisnis terpadu (Integrated agribusiness model). Jakarta: Agricultural human resource development board of agribusiness enterpreneurship development center, Department of Agriculture.

Ahyari, A. 1996. Manajemen Produksi: Perencanaan Sistem Produksi. Yogyakarta: BPFE.

Badan Litbang Pertanian RI. 2017. Kawasan Rumah Pangan Lestari Jakarta: Kementerian Pertanian Republik Indonesia. Beierlein, J. G., Schneeberger, K. C., \& Osburn, D. D. 1986. Principles of Agribusiness Management.
Englewood Cliffs, New Jersey: Prentice-Hall.

Covello, J. A., \& Hazelgren, B. J. 2004. Rencana Bisnis Lengkap (The complete book of business plans). Batam: Interaksara.

Cramer, G. L., Jensen, C. W., \& Southgate, D. D. J. 1997. Agricultural economics and agribusiness ( 7 ed.). New York: John Wiley \& Sons, Inc.

Downey, W. D., \& Erickson, S. P. 1987. Agribusiness

Management. New York: McGraw-Hill.

Kotler, P. 1997. Manajemen Pemasaran: Analisis, Perencanaan, Implementasi, dan Kontrol (H. Teguh, \& R. A. Rusli, Trans.) (9 ed.). Jakarta: Prenhallindo.

McGregor, M. J. 1997. A System View of Agribusiness. Agribisnis, 1(1 \& 2): 1-8.

Sjah, T., Rosmilawati, \& Zainuri. 2012. Rencana Bisnis: Untuk pengusaha kecil dan pemula dalam usaha pengolahan hasil pertanian. Mataram: Mataram University Press.

Soekartawi. 1991. Agribisnis Teori dan Aplikasi. Jakarta: Rajawali Press.

Swastha, B., \& Irawan. 2005. Menejemen Pemasaran Modern (2 ed.). Yogyakarta: Liberty. 
Tohir. 2017. Manajemen Usaha,

pelatihan pengolahan hasil Wikipedia, Vol. 2017.

Walker, M. A. 2009. Agritourism: Ideas and Resources. Petersbug: Virginia Cooperative Extension.

Wikipedia. 2016. Agritourism, Vol. 2016: Wikipedia.

$\begin{array}{rrr}\text { Zainuri, Handayani, } & \text { B. } & \text { R., } \\ \text { Werdiningsih, } & \text { W., } & \& \\ \text { Widyasari, W. } & \text { 2017. Modul }\end{array}$ pertanian untuk meningkatkan ekonomi perempuan di Kabupaten Lombok Utara. Mataram: Konsorsium Karya TerpaduMCAI. 